\title{
DYNAMIC MODELLING SYSTEM OF INDONESIA'S CRUDE PALM OIL SUSTAINABLE SUPPLY CHAIN MANAGEMENT
}

\author{
Fety Nurlia Muzayanah*), Eko Ruddy Cahyadi**), and Jono M. Munandar*) \\ ${ }^{*}$ Study Program of Management Science, Postgraduate School, Bogor Agricultural University \\ Jl. Agatis IPB Darmaga Campus, Bogor 16680 \\ ${ }^{* *}$ Department of Management, Faculty of Economics and Management, Bogor Agricultural University \\ Jl. Agatis IPB Darmaga Campus, Bogor 16680
}

\begin{abstract}
The agricultural sector has an important role in economic activity in Indonesia. It is reflected from its contribution to the Gross Domestic Product (GDP) of approximately 13.46 percent in 2016 and its ability to absorb 31.86 percent of Indonesian workforce in February 2017. The objectives of this study are to simulate the scenarios of increasing sustainable production in the model of sustainable supply chain management of Crude Palm Oil (CPO) and to formulate policy alternatives for the development of sustainable supply chain management of Indonesian CPO. Data used in this research were primary data and secondary data. The analyzer used in this research was dynamic system model by simulating the replanting policy, moratorium, and environmentally friendly cultivation technique. The result of this research shows that the dynamic system model of sustainable supply chain management CPO Indonesia built is valid, both through structure test and performance model test. Scenario 4 provides the greatest PV of all scenarios of $10.99 \%$ larger than the baseline. The best policy alternative is to implement replanting and sustainable agriculture practices with zero burning on the new land clearing process to give better net benefits value.
\end{abstract}

Keywords: cpo, dynamic modelling, supply chain management, sustainability

\begin{abstract}
Abstrak: Sektor pertanian memiliki peran penting dalam kegiatan perekonomian Indonesia. Hal ini dapat dilihat dari kontribusinya terhadap Produk Domestik Bruto (PDB) yang cukup besar yaitu sekitar 13,46 persen pada tahun 2016 dan mampu menyerap 31,86 persen tenaga kerja Indonesia pada Februari 2017. Tujuan penelitian ini adalah mensimulasikan skenario peningkatan produksi lestari pada model manajemen rantai pasok berkelanjutan Crude Palm Oil (CPO) dan merumuskan alternatif kebijakan untuk pengembangan manajemen rantai pasok berkelanjutan CPO Indonesia. Data yang digunakan dalam penelitian ini merupakan data primer dan data sekunder. Alat analisis yang digunakan dalam penelitian ini adalah model sistem dinamik dengan mensimulasikan kebijakan peremajaan, moratorium pembukaan lahan baru, dan teknik budidaya ramah lingkungan. Hasil penelitian model sistem dinamik manajemen rantai pasok berkelanjutan CPO Indonesia yang dibangun dinyatakan valid baik melalui uji struktur maupun uji kinerja model. Skenario 4 memberikan nilai PV terbesar dari semua skenario, yaitu 10,99\% lebih besar dari baseline. Alternatif kebijakan yang terbaik adalah dengan menerapkan peremajaan dan praktik budidaya berkelanjutan dengan zero burning pada proses pembukaan lahan sehingga dapat memberikan nilai manfaat bersih yang lebih baik.
\end{abstract}

Kata kunci: cpo, keberlanjutan, manajemen rantai pasok, model dinamik

\footnotetext{
${ }^{1}$ Corresponding author:

Email: fetynurlia@gmail.com
} 


\section{INTRODUCTION}

Agricultural sector has an important role in the economic activity in Indonesia. It is reflected from its relatively high contribution to the Gross Domestic Product (GDP) of approximately $13.46 \%$ in 2016 (BPS, 2017a) or the second highest after manufacturing industry sector. Agricultural sector in Indonesia was also able to absorb $31.86 \%$ of labor in February 2017 (BPS, 2017b). Agricultural sector is a relatively strong sector in facing economic crisis and dependable in national economic recovery. One larger potential subsector is plantation subsector. Plantation subsector contribution to the GDP was $3.57 \%$ in 2015 and it was the highest in Agriculture, Livestock, Hunting, and Agricultural Service sector (BPS, 2016). One plantation sector commodity that has an important role on the economic activity of Indonesia is palm oil. Palm oil is one Indonesia export commodity that is important in gaining national income after oil and gas (BPS, 2016).

Government and industry in the developing countries expand their biomass production sector due to their sight of opportunity in economic, social, and environmental developments (Boons and Mendoza, 2010). Based on the data of BPS (2016), Indonesia's palm oil plantation area in the last six years has increased by approximately 2.77 to $11.33 \%$ per year. In 2010, the area was recorded to be as wide as 8.55 million hectares and increased by 10.75 million hectares in 2014 (an increase by $25.80 \%$ ). In 2015 , the palm oil plantation area is estimated to be increased within $5.07 \%$ in 2014 to 11.30 million hectare (BPS, 2016).

The result of the study conducted by Nayantakaningtyas and Daryanto (2012) showed that the competitiveness of Indonesia's CPO is considerably high, but a proper strategy is still required to strengthen $\mathrm{CPO}$ products especially for their derived products. The problem faced by CPO industry is its sustainability of supply chain. The study regarding supply chain had been done many times (Linton et al. (2007); Seuring \& Muller (2008); Dues et al. (2013)). Seuring \& Muller (2008) did literature review on sustainable supply chain management as many as 191 writings published from 1994 to 2007. Hassini et al. (2012) reviewed the studies regarding sustainable supply chain management in the last decade and analyzed them fromdifferent perspectives. Dues et al. (2013) recommend a company strategy to integrate the green practice on the company's slim-supply-chain-management to match it with the environment concerns.

Sustainability issue is often faced by palm's supply chain due to the presumption that palm oil plantation is a trigger of degradation and soil pollution (Obidzinki et al. 2012), green house emission (Achten and Verchot, 2011; Danielsen et al. 2008), decrease of biodiversity (Danielsen et al. 2008), and land conflicts (Feintrenie et al. 2010; Rist et al. 2010; Obidzinki et al. 2012; Manik et al. 2013). To fulfill the demands from both domestic and foreign countries, Indonesia is still conducting extensification by new palm land clearing that causes deforestation. Palm oil expansion is still deemed to be the main trigger to deforestation in Indonesia (Sheil et al. 2009). In 2010, several food-processing companies declared that they canceled the contract with a palm oil company that is involved in deforestation in Indonesia (Tata et al. 2014). Deforestation gives impact to the decrease of environment quality, decrease and disappearance of biodiversity, soil depletion, change of surface water flow, increase of soil erosion, and environmental pollution because of the usage of fertilizer and pesticide in high dose, green house emission, and various negative impact to the eco-function that is caused by tropical forest ecosystem when plantations replace forest and peat land (Manurung, 2001).

The other problem is the assumption of burning as the fastest and cheapest method to clear the plantation land (Gouyon and Simorangkir, 2002). Manurung (2001) stated that the practice of natural forest conversion to plantation land often becomes the main cause of forest fire and other wildfires in Indonesia. They happen because the land cleaning activities to create a palm oil plantation land are carried out by burning trees for making it fast and having low-cost. This gives impact on human life, livelihood, health, biodiversity and habitat, and potentially causes global warming (Simorangkir, 2007). Economic cost of the pollution due to disappearance of forests, degradation and smog is estimated to reach $\$ 2,300-3,500$ million, with the addition $\$ 2,800$ million because of the carbon emission (Tacconi, 2003). In 2010, several food-processing companies declared that they canceled the contract with the palm oil company that is involved in deforestation in Indonesia (Tata et al. 2014). 
However, the increased production due to new land clearing will enhance labor absorption and increase social welfare and social development especially in rural areas (Boons and Mendova, 2010; Widodo et al. 2010). Reviewed from the broader benefit, it is estimated by industry that palm oil sector had saved six million people from poverty (Goenadi, 2008). There is also a national benefit in it: the export income gained by Indonesia reached more than $\$ 12,000$ million in 2007 (Goenadi, 2008). To improve the image of Indonesia regarding sustainability issue, Indonesia's government has a program to re-organize palm oil land, including the effort to increase the existing land's production, replanting and palm oil plantation license moratorium (Aria, 2016). Previously, Indonesia has already issued three Inpres (Instruksi Presiden) or President's Instruction -one of the legal rule in Indonesia- regarding the postponement of new licensing and the improvement of primary forest governance and peat land. They included Inpres number 10 year 2011, Inpres number 6 year 2013 and Inpres number 8 year 2015 .

Based on the previous explanation, palm oil industry faces an environmental impact problem and its consequence on society's social condition. According to Widodo (2010), natural resource management, including CPO's sustainable supply chain is a difficult duty, as a result of dynamism, uncertainty, and contradicting objective (ecology, economy, and social), so, the natural resource management discussion can be conducted by the dynamic model approach. Therefore, to discuss sustainable supply chain management on the Indonesia's palm oil production, the dynamic model approach by considering economic, social, and environmental aspects should be conducted. The objectives of this study are to simulate the scenarios of sustainable production increase on the CPO's sustainable supply chain management, and to formulate policy alternative for the development of CPO's sustainable supply chain management in Indonesia.

\section{METHODS}

In this study, data that were used were primary data and secondary data. Primary data were obtained from the interview with experts conducted in Bogor to confirm the systematic thinking on the formation of research model. Data collection technique was carried out purposely in line with the expertise of the selected respondents. The secondary data were obtained from literary study by learning and observing various literatures and previous studies in the form of books, articles, journals, and internet regarding this study.

Data processing and analyzing method used in this study was the dynamic model. It was used to simulate the production increase scenario by rejuvenating and reducing the environmental cost through palm oil plantation and application of zero burning on the palm oil plantation opening. Dynamic model is an abstraction and simplification of a complex system, but it is strived to be able to represent the system well. Moreover, standing on the obtained dynamic model, policy scenario simulation based on the logical developed assumption is conducted (Sterman, 2000). The model of this study will be built by using time series data, information, rules and government policies regarding palm oil, and reference on various models that were developed for palm oil or the other commodity. Schematically, thinking-conceptframework of the study is shown in the Figure 1.

According to Widodo et al. (2011), steps that are done in problem solving by dynamic system approach are:

\section{Problem definition and formulation}

Before defining and formulating the problems, understanding the system that will be analyzed should be done first. The problem in palm oil supply chain management is the fact that the increase ofCPO production by palm oil plantation expansion will increase $\mathrm{CPO}$ industry income and increase palm oil plantation labor absorption. However, palm oil plantation land expansion will give impact on the environment degradation and increase of the environmental cost.

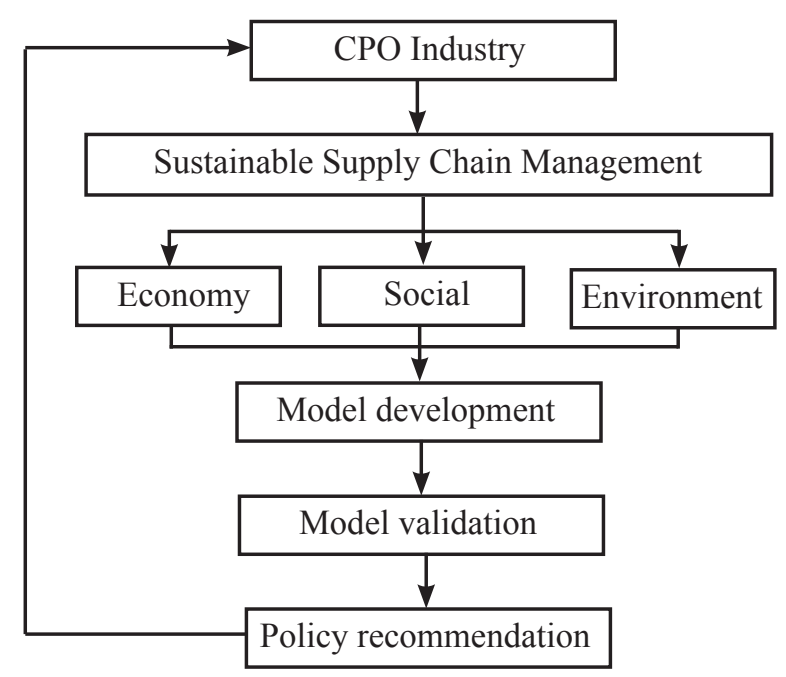

Figure 1 Research framework 


\section{Conceptual system formation}

This step contains the identification of the subjects involved in the system (system member), and the relationship among the members is used as a base to form causal loop and analyze the system limitation. The limitation is carried out to simplify the observation of analyzed system. The next approach is to form a causal-loop diagram as shown in the Figure 2. The causal loop was developed from the study by Widodo et al. (2010).

\section{Model formulation}

Model formulation means converting inter-element relations or inter-member relations in the system to computer language (programming language). In this study, subsystem dividing was done to give scope limitation to the steps that will be conducted. Submodels in this study include (1) production policy submodel; (2) economy sub-model; (3) social sub-model; and (4) environment sub-model (Figure 3).

\section{Model simulation and validation}

Model is simulated to observe the model's behavior which is a description of the real system behavior. Model simulation was carried by five scenarios as follows:

a. Scenario 1. It is the baseline that represents the current condition, with the assumption that the average increase of new plantation is $5.66 \%$ from the total plantation (BPS, 2016), the replanting of $1.09 \%$ from total plantation (Badrun, 2010), fire opportunity of $4.48 \%$ from total plantation (World Bank, 2016) and labor per hectare area of 0.7 person/ hectare area (Info Sawit, 2015).

b. Scenario 2 . Replanting $70 \%$ of the plants whose age is more than 25 years old or unproductive plants (TTM). This assumption measurement $(70 \%)$ was used because of the high replanting cost and fund insufficiency to do replanting. The current obstacle that is faced by the farmers is the fact that replanting is a new innovation for them, their worries to lose their livelihood if the replanting is carried out, and the insufficiency of capital that they have (Anggraeni et al. 2016). Replanting cost is within Rp25-30 million per hectare according to Herman and Pranowo (2011) and Rp30 million per hectare according to Ferry and Herman (2010). New palm oil plantation land clearing is conducted based on the historical data condition.

c. Scenario 3. Moratorium simulation starting from 2016 to 2020. Replanting is based on historical data (baseline).

d. Scenario 4. Replanting simulation based on the plantation number with TTM status, and it is assumed that $75 \%$ of new palm oil plantation land clearing will be done sustainably by applying zero burning. According to Muin (2013), average cost of land cleaning per hectare is Rp9,807,934.

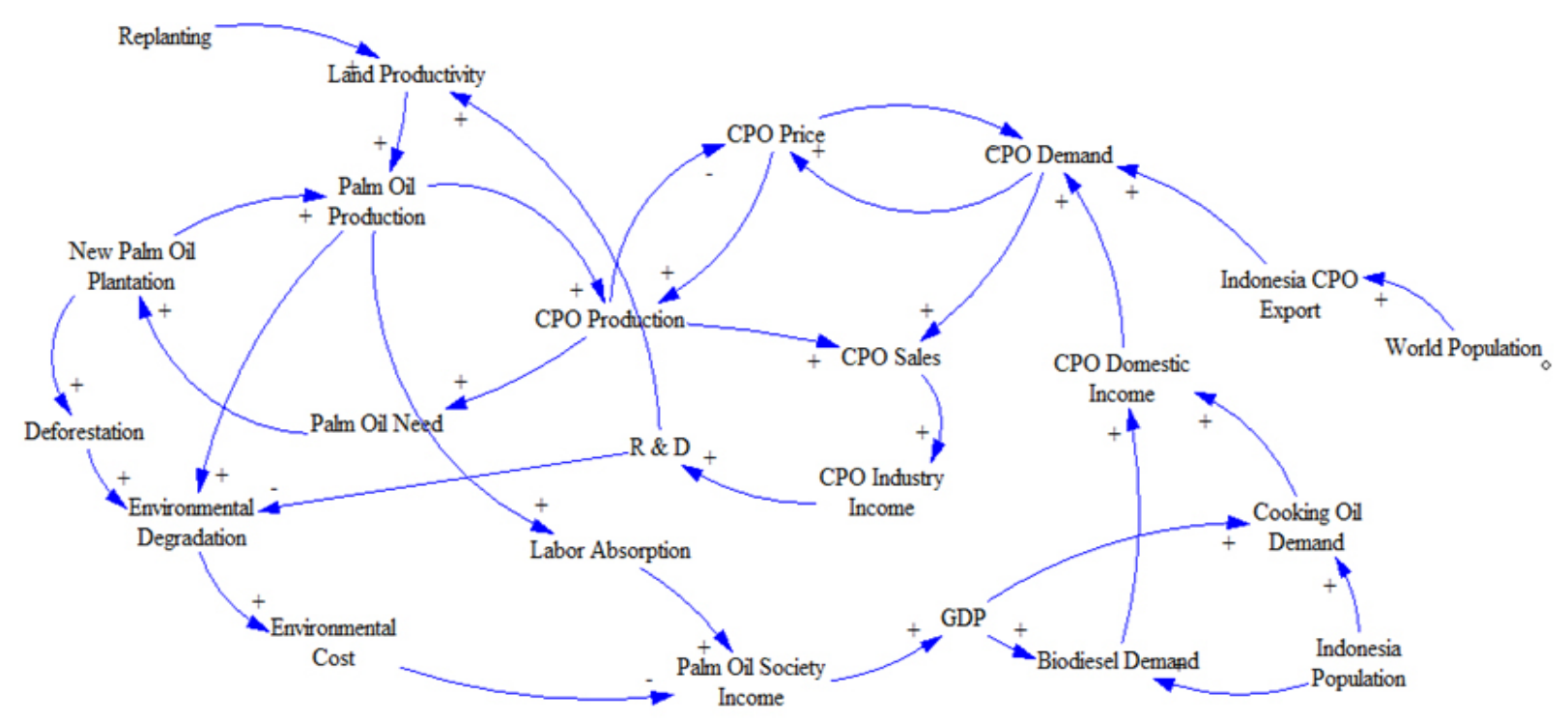

Figure 2. Causal-loop 


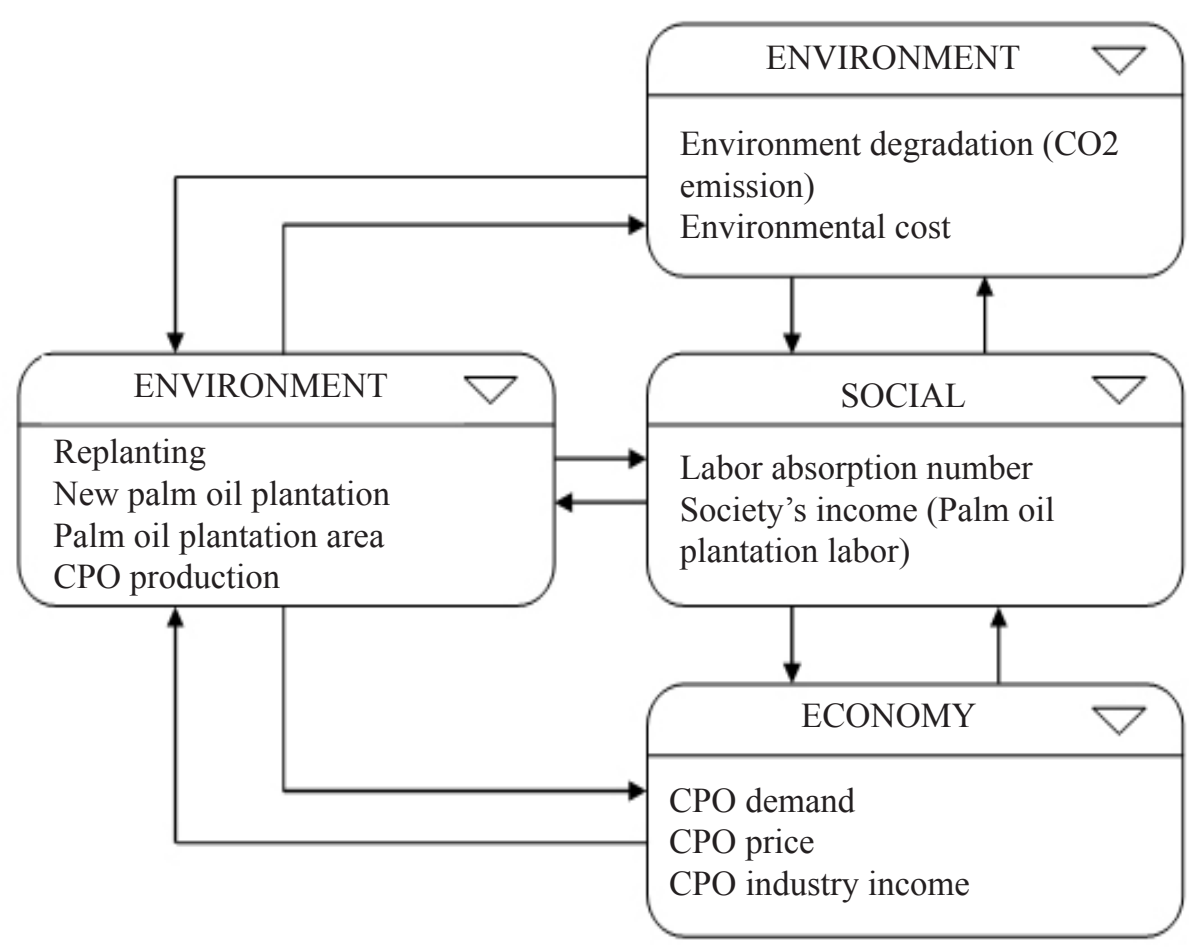

Figure 3. Research model

e. Scenario 5. Replanting simulation within $70 \%$ from the plantation number with TTM status, and it is assumed that $75 \%$ of new palm oil plantation land clearing is conducted sustainably by applying zero burning. According to Daalen and Thissen (2010), validation in dynamic system modeling is able to be conducted by several ways: direct structure test without running the model, structureoriented behavior test with running the model, and quantitative behavior pattern comparison. Validation in this model is done statistically by using independent-sample $t$ test to test the average significance difference from the actual data and simulation data. If the significance level is greater than $\alpha$ value which is 0.05 , then the average difference of actual data and simulation data is not significant (Widodo et al. 2010).

\section{Policy/decision analysis and improvement}

The reliability of the model was tested, and the result will be used to observe or test the condition that is analyzed. By using this model, system condition, system behavior and system response to the policy regarding system are able to be observed. Therefore, the adjustment of policy and system structure is able to be carried out immediately if needed.

\section{Policy/decision implementation}

In this step, analysis on the dynamic system model simulation result is conducted so that the most suitable and proper policy to be applied in the field will be able to be discovered.

\section{RESULTS}

\section{Dynamic Model of Indonesia's CPO Sustainable Supply Chain Management}

The research model in this study was divided into four sub-models as follows:

\section{Production policy sub-model}

In the production policy sub-model, palm oil plantation land area is divided based on the plant condition by BPS. In the initial forming of the model, it was assumed that there has been no moratorium so far. In this sub-model, CPO production from year to year will be observed with driving-variables from production policy, replanting and new palm oil plantation land clearing. 


\section{Social sub-model}

The existence of palm oil plantation generates a number of positive and negative many social impacts. The positive impacts include local labor absorption (Mc Cathy, 2010; Manik et al. 2013), local economy/farmer income (Belcher et al. 2004; Sandker et al. 2007; Rist et al. 2010; Cahyadi and Waibel 2013; ).

\section{Economy sub-model}

Economy sub-model was developed with several variables i.e. demand and income of the palm oil (CPO) industry. Demand is differentiated to overseas demand (export) and domestic demand. CPO overseas demand is assumed to be increased in line with the growth of world's population. Sayer et al. (2012) said that palm's global demand will always increase as a response to the growth and increase of global population, income, and development of bio-fuel market nowadays. Domestic demand is reflected from cooking oil and bio-diesel domestic demands. CPO price is assumed to be increased randomly in line with the increase of previous historical data.

\section{Environment sub-model}

In this study, environment sub-model focused on the environmental impact in the form of $\mathrm{CO} 2$ gas emission and the loss cost of forest fire. Forest fire cost data were obtained from the data of World Bank (2016), and this cost contains loss cost in the field of agriculture (plantation plant and crop), living environment (disappearance of biodiversity and carbon emission), forestry, manufacture and mining, trade, transportation, tourism, health, education and firefighting cost. In the environmental sub-model, there was the description on how the expansion of new plantation will increase $\mathrm{CO} 2$ emission due to land conversion.

Research model that was further developed from Widodo et al. (2010) as a whole is shown in Figure 4.

The simulation results from the five scenarios obtained from the study showed the different CPO production value, labor absorption, environmental cost, and net benefit value. Net benefit value that was used in this study was only considering CPO industry's income from the CPO sale, society's income and employer wage, environmental cost, replanting cost, and land clearing cost.

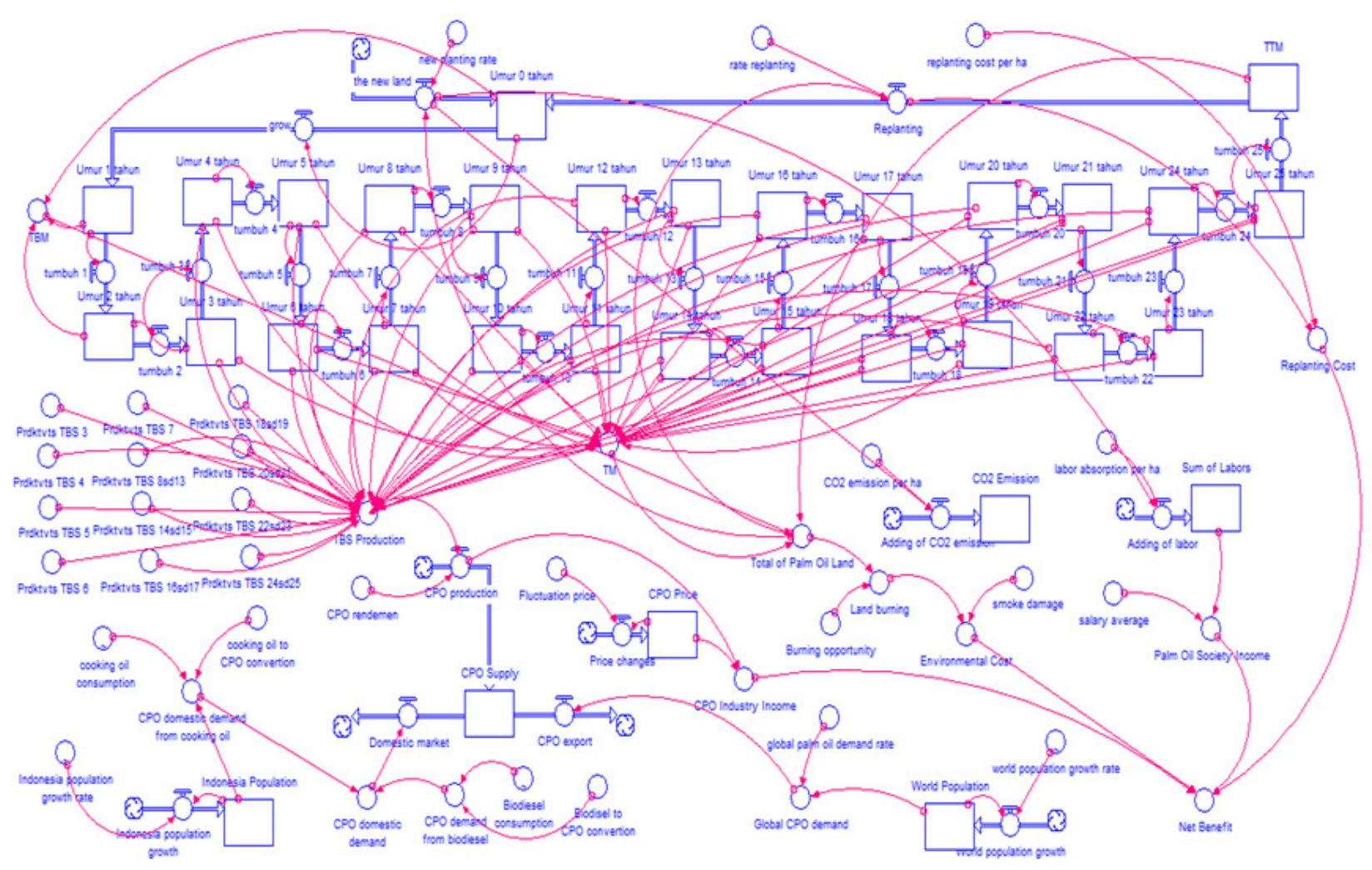

Figure 4. Dynamic model of indonesia's cpo sustainable supply chain management 


\section{CPO Production}

Based on the simulation result, the highest $\mathrm{CPO}$ production was obtained in the simulation of scenario 4 , showing that the highest production was obtained from the replanting policy based on the need, that is palm oil plantation area with TTM status. The lowest CPO production was obtained from scenario 3 , where the 5year moratorium was implemented. In the replanting policy, productivity is able to increase so that it will increase CPO production. It is concluded that the longer moratorium policy occurs, the lower CPO production will be. The comparisons of CPO production among the scenarios are shown in Figure 5.

\section{Labor Absorption}

Simulation result showed the same labor absorption in scenarios 1, 2, 4 and 5 whereas scenario 3 was the scenario with the lowest labor absorption. This happened because of the existence of moratorium trade off that decreases labor absorption due to the reduction of new palm oil plantation land. The longer the moratorium occurs, the lower the labor absorption will be. The comparisons of labor absorption among the scenarios are shown in Figure 6.

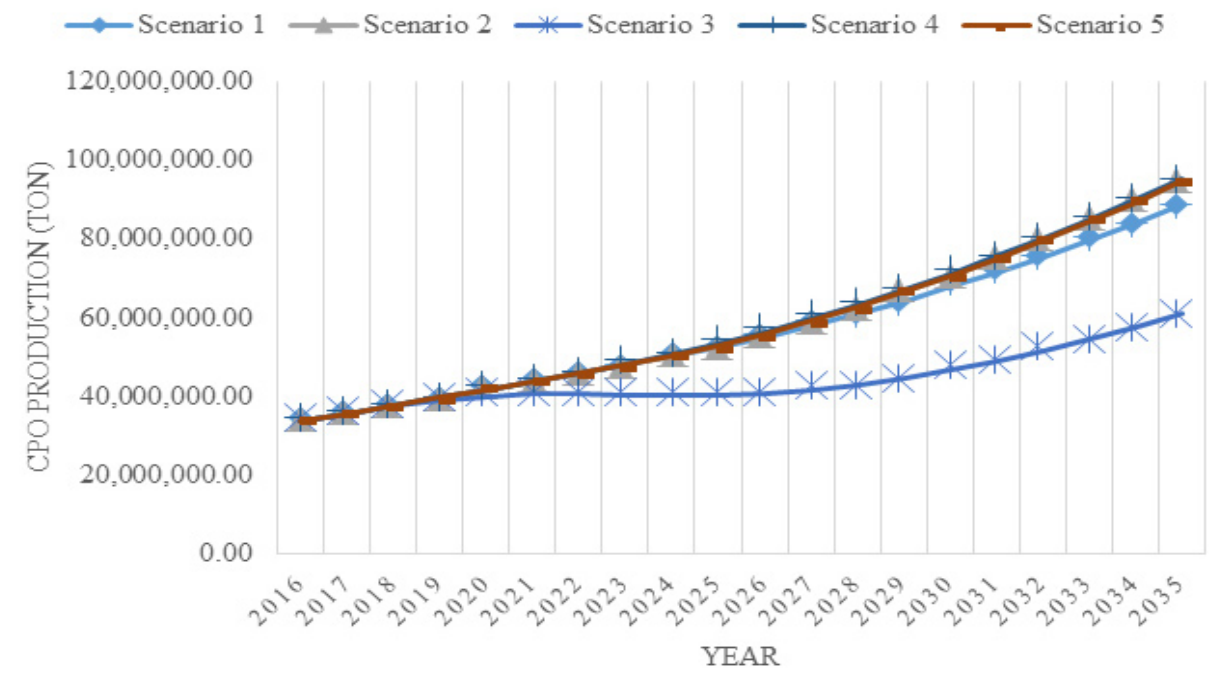

Figure 5. Comparison of CPO productions between scenarios

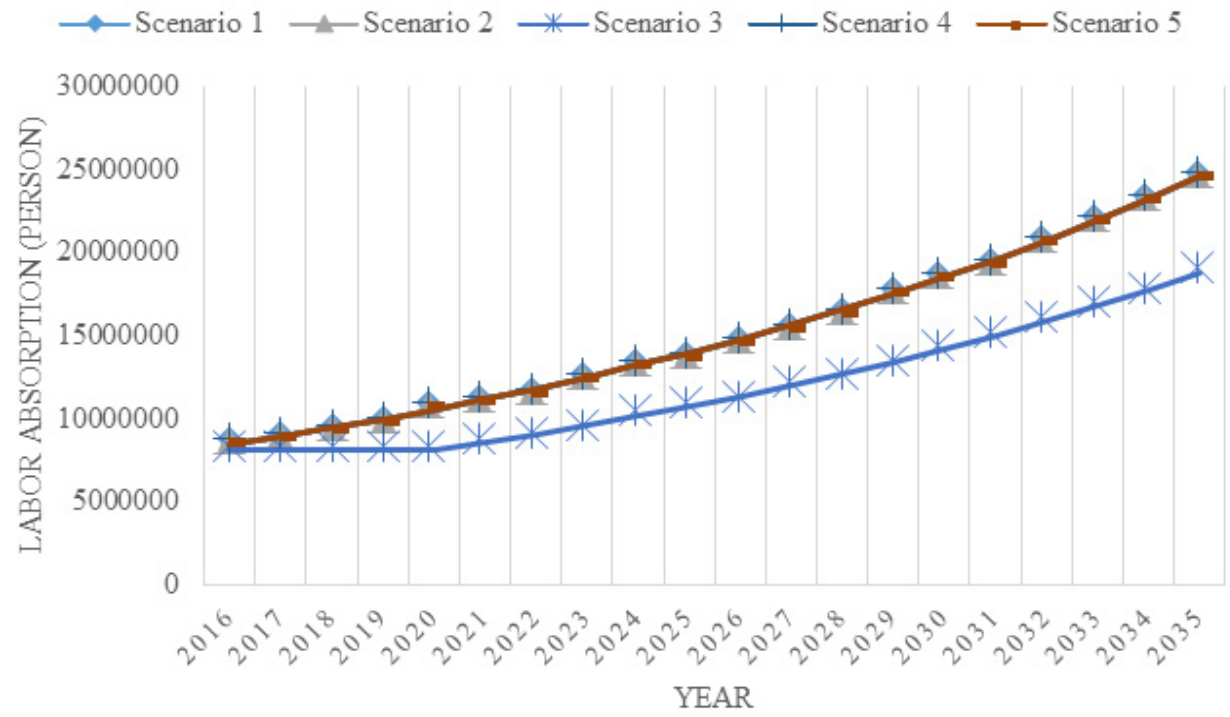

Figure 6 . The comparison of labor absorption between scenarios 


\section{Environmental Cost}

The lowest environmental cost was obtained from the simulations of scenarios 4 and 5 where eco-friendly land clearing (zero burning) was applied. It showed that an eco-friendly new land clearing had an ability to reduce environmental cost due to its possibility to reduce wildfire opportunity. Although there was still a trade off with the additional cost for land clearing. For the new land clearing moratorium, it had an ability to reduce the environmental cost even though in a smaller amout compared to the eco-friendly new land clearing. The comparisons of environmental cost among the scenarios are shown in Figure 7.

\section{Comparison of Net Benefit Value}

The highest net benefit value was obtained from scenario

4 i.e. replanting policy and sustainable land clearing. It shows that the larger the rejuvenated plantation area along with the application of eco-friendly practices, the higher the net benefit value will be. If the values of total net benefits from 2017 to 2035 are measured, with i value to be $3.89 \%$ (average value of inflation of January - Mei 2017), then scenario 2 will have a greater Net
Present Value (NPV) from scenario 1 as much as $0.14 \%$, scenario 3 will have smaller NPV of $1.43 \%$, scenario 4 will have greater PV of $10.99 \%$, and scenario 5 will have greater NPV of $10.96 \%$. Net benefit measurement in this study only used the value from CPO industry income that was obtained from CPO selling plus the society's income from palm oil plantation employer's wage, minus replanting cost, environmental cost due to fired and the other additional cost for zero burning land clearing, and it was still not considering production cost and transportation cost. Net benefit costs for the four scenarios are shown in the Figure 8.

Based on the Figure 8, it is reflected that scenario 4 is the best scenario compared to the other scenarios. This happened because scenario 4 gave the highest net benefit value. It showed that replanting and sustainable practices are able to give positive benefits for the environment, social and economy. With the replanting area that becomes larger, CPO's productivity is able to increase even though; on one hand; this will increase the cost and bring out waiting period before the palm oil tree bear fruits. On the other hand, the application of sustainable practices is able to reduce the cost of environmental negative impacts even though there is an additional cost in its application.

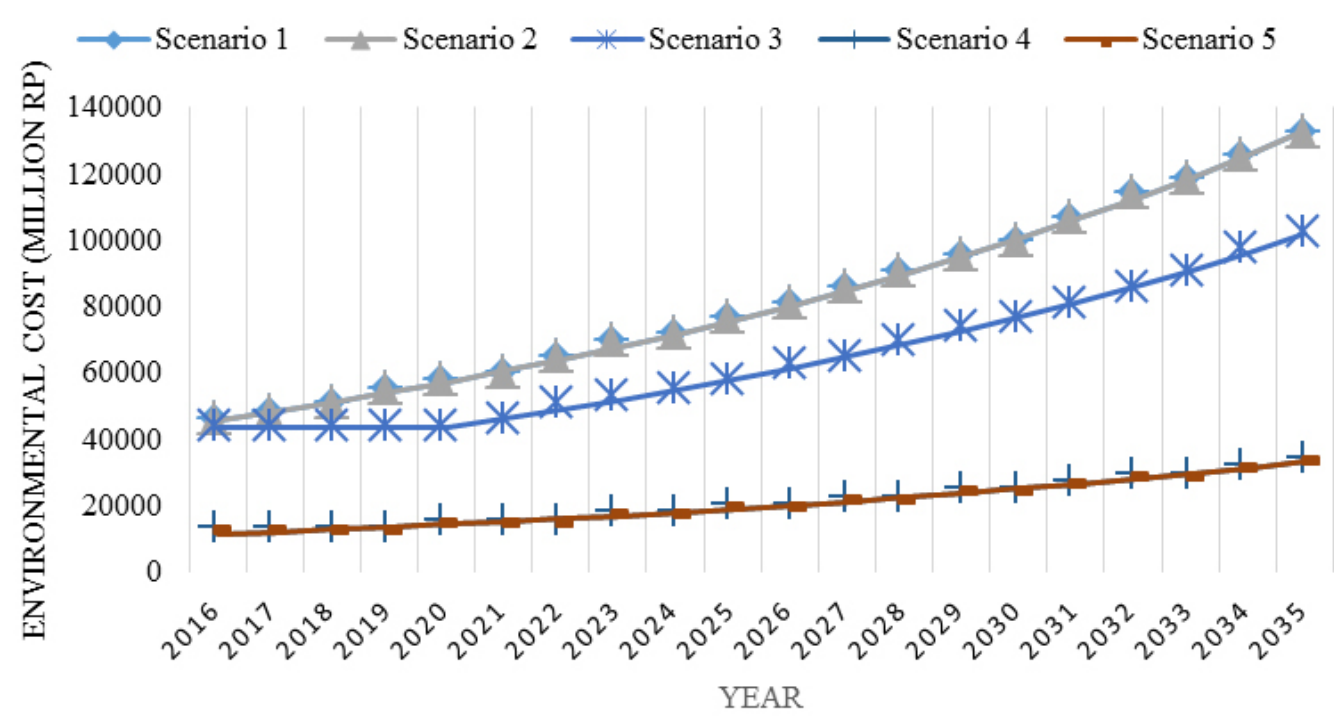

Figure 7. The comparison of environmental cost between scenarios 


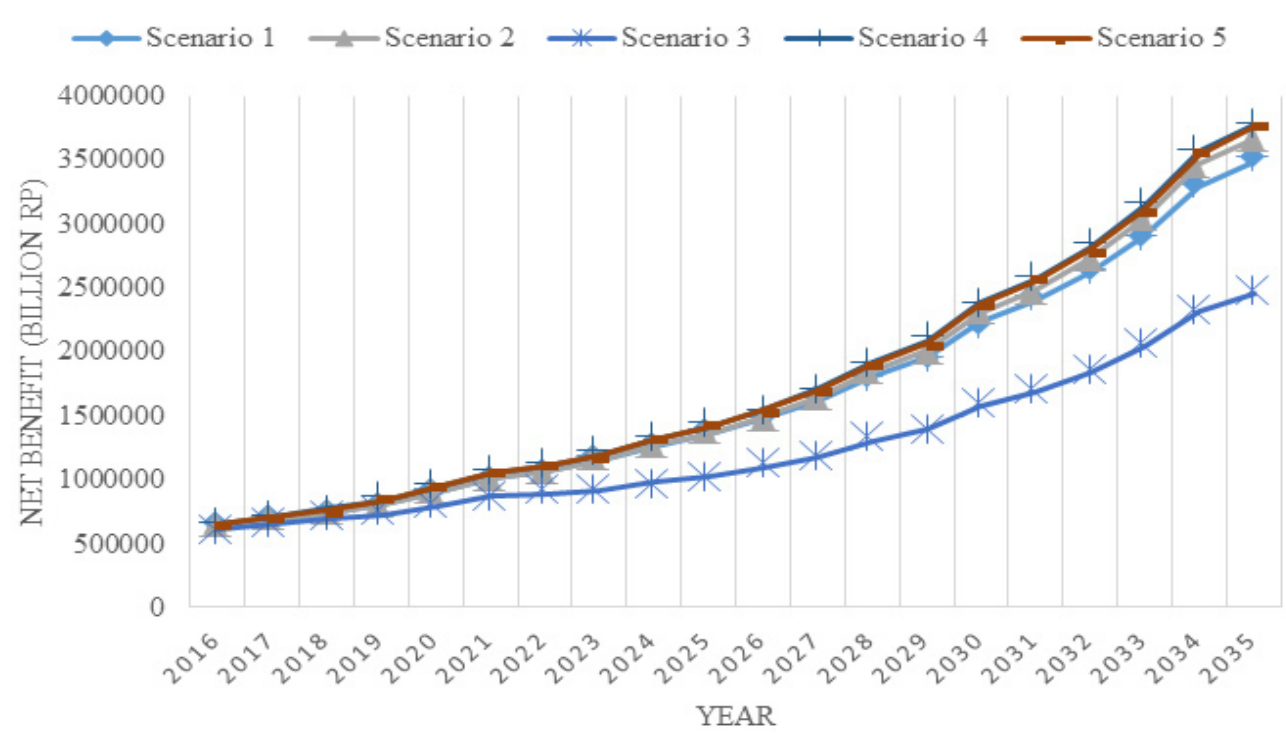

Gambar 8. The comparison of net benefit value between scenarios

\section{Model Validation}

Validationthatwas donein thismodelconsists of structure validity test and model performance validity test. In the structure validity test, there was no inconsistency in the use of dimension found. Validation in this model was carried out statistically by using independent-sample $t$ test to test the average significance difference between actual data and simulation data. Data that were used in this validation were total number of plantation data and CPO production from 2011 to 2015. Based on the statistic test, significance value that was obtained for total palm oil plantation was 0.813 and CPO production 0.895 greater than $\alpha$ value $(0.05)$. Therefore, the conclusion is that there is no significance difference between actual data and simulation data.

\section{Policy Alternative for the Development of Indonesia's CPO Supply Chain Management}

From the five scenarios, replanting that was done alongside the eco-friendly environment gives the highest financial benefit. Financial benefit value was determined by CPO industry income and society's income, while factors that affect in negative way included replanting cost, environmental cost and cost to apply eco-friendly cultivation practices. Other than production policy improvement, policy to increase Indonesia's CPO market share is also needed for both overseas and domestic markets so that it will be able to increase CPO demands. Through eco-friendly practice, the cost of wildfire is possible to be reduced even though there will be another additional cost in the application.
Other than that, it is also able to increase international society's acceptance to Indonesia's eco-friendly CPO product. The best policy alternative in this study was replanting application based on the land needs and land clearing with the consideration over sustainability (zero burning).

\section{Managerial Implications}

Based on result, replanting based on the plantation number with TTM status (100\% TTM) can increase production by $3.582 \%$, while replanting with $70 \%$ TTM can only increase production by $2.915 \%$ from baseline condition. Replanting is able to increase plantation productivity with the result that increase in $\mathrm{CPO}$ production is without massive extension of plantation.

\section{CONCLUSIONS AND RECOMMENDATIONS}

\section{Conclusions}

Dynamic system model of Indonesia's CPO sustainable supply chain management that was built was stated to be valid and proper by the structure test and model performance test. Simulation with five different scenarios gave different results. Scenario 4 gave the highest scenario of $10.99 \%$ greater than the baseline. CPO industry income and society's income gave positive impact to the net benefit value, while the other factors that gave negative impact included replanting cost, environmental cost and the cost to apply eco-friendly cultivation practices. The best policy alternative is to 
apply replanting and sustainable practices with zero burning in the land clearing process so that it would give better net benefit value. The larger the rejuvenated plantation area, the higher the CPO production will be.

\section{Recommendations}

Recommendation of this study is that eco-friendly palm oil plantation management should be increased to reduce negative impacts from the social and environmental aspects. Research is required to increase Indonesia's $\mathrm{CPO}$ productivity and reduce wildfire potency in the dry season. Research model needs to be improved by adding variables that have not been observed such as production cost, transportation cost, research cost, and other variables affecting $\mathrm{CPO}$ price with more complete data quantity and quality.

\section{REFERENCES}

Achten WMJ, Verchot LV. 2011. Implications of biodiesel-induced land-use changes for $\mathrm{CO} 2$ emissions: Case studies in Tropical America, Africa, and Southeast Asia. Ecology and Society, 16(4), art. 14. doi:10.5751/ES-04403-160414.

Anggreani S, Muljono P, Sadono D. 2016. Partisipasi petani dalam replanting kelapa sawit di Provinsi Jambi. Jurnal Penyuluhan 12(1): 1-14. https:// doi.org/10.25015/penyuluhan.v12i1.11315.

Aria P. 2016. Moratorium Sawit akan Diperpanjang LimaTahun.https://m.tempo.co/read/ news/2016/07/16/090787984/moratoriumsawit-akan-diperpanjang-lima-tahun.[14 September 2016].

Badrun M. 2010. Tonggak Perubahan melalui PIR Kelapa Sawit Membangun Negeri. Jakarta: Direktorat Jenderal Perkebunan.

Belcher B, Rujehan, Imang N, Achdiawan R. 2004. Rattan, rubber, or oil palm: cultural and financial considerations for farmers in Kalimantan. Economic Botany 58 (Supplement): S77-S87.https://doi.org/10.1663/00130001(2004)58[77:RROOPC]2.0.CO;2.

Boons F, Mendoza A. 2010. Constructing sustainable palm oil: how actors define sustainability. Journal of Cleaner Production 18:1686-1695. https://doi.org/10.1016/j.jclepro.2010.07.003.

[BPS] Badan Pusat Statistik. 2014. Statistik Kelapa Sawit Indonesia 2013. Jakarta: BPS.
[BPS] Badan Pusat Statistik. 2016. Statistik Kelapa Sawit Indonesia 2015. Jakarta: BPS.

[BPS] Badan Pusat Statistik. 2017a. Pendapatan Nasional Indonesia (National Income of Indonesia) 2012-2016. https://www.bps.go.id/ website/pdf_publikasi/Pendapatan-NasionalIndonesia-2012---2016.pdf [5 September 2017].

[BPS] Badan Pusat Statistik. 2017b. Penduduk 15 Tahun Ke Atas yang Bekerja menurut Lapangan Pekerjaan Utama 1986 - 2016. https://www.bps. go.id/linkTabelStatis/view/id/970 [24 September 2017].

Cahyadi ER, Waibel H. 2013. Is contract farming in the Indonesian Oil Palm industry pro-poor? Journal of Southeast Asian Economies 30(1): 62-76. https://doi.org/10.1355/ae30-1d.

Daalen V, Thissen WAH. 2001. Dynamics Systems Modelling Continuous Models. Delft: Faculteit Techniek, Bestuur en Management (TBM). Technische Universiteit Delft.

Danielsen F, Beukema H, Burgess ND, Parish F, Bruehl CA, Donald PF, Phalan B, Reijnders L, Strubig M, \& Fitzherbert EB. 2008. Biofuel plantations on forested lands: Double jeopardy for biodiversity and climate. Conservation Biology 23(2): 348358. Doi:/10.1111/j.1523-1739.2008.01096.x.

Dues CM, Tan KH, \& Lim M. 2013. Green as the new Lean: how to use Lean practices as a catalyst to greening your supply chain. Journal of Cleaner Production (40): 93-100. https://doi. org/10.1016/j.jclepro.2011.12.023.

Feintrenie L, Chong WK, Levang P. 2010. Why do farmers prefer oil palm? lessons learnt from Bungo district, Indonesia. Small-Scale Forestry 9(3): 379-396. https://doi.org/10.1007/s11842010-9122-2.

Ferry Y, Herman M. 2010. Peremajaan kelapa sawit. Infotek Perkebunan 2 (10): 28-38.

Goenadi DH. 2008. Perspective on Indonesian palm oil production. Paper to 41st IPC Seminar Food, Fuel, and Forests: A Seminar on Climate Change, Agriculture, and Trade. Bogor, Indonesia, 12 May 2008. International Food and Agricultural Trade Policy Council. http://www.agritrade.org/ events/documents/Goenadi2008.pdf (14 Juli 2016).

Gouyon A, Simorangkir D. 2002. The economics of fire use in agriculture and forestry: a preliminary review for Indonesia. Project Fire Fight South East Asia, Jakarta.

Hassini E, Surti C, Searcy C. 2012. A literature review 
and a case study of sustainable supply chains with a focus on metrics. International Journal of Production Economics 140: 69-82. https://doi. org/10.1016/j.ijpe.2012.01.042.

Herman M, Pranowo D. 2011. Produktivitas jagung sebagai tanaman sela pada peremajaan sawit rakyat di Bagan Sapta Permai Riau. Prosiding Seminar Nasional Serealia, 213-219.

Info sawit. 2015. Kebun sawit butuh 7 juta tenaga kerja. http://www.infosawit.com/mobile/index.php/ news/detail/kebun-sawit-butuh-7-juta-tenagakerja.

Linton J D, Klassen R, Jayaraman V. 2007. Sustainable supply chains: An introduction. Journal of Operations Management 25(6): 1075-1082. https://doi.org/10.1016/j.jom.2007.01.012.

Manik Y, Leahy J, Halog A. 2013. Social life cycle assessment of palm oil biodiesel: a case study in Jambi Province of Indonesia. The International Journal of Life Cycle Assessment 18(7):13861392.https://doi.org/10.1007/s11367-0130581-5.

Manurung EGT. 2001. Analisis Valuasi Ekonomi Investasi Perkebunan Kelapa Sawit di Indonesia. Jakarta: The NRM Program.

McCarthy J. 2010. Processes of inclusion and adverse incorporation: oil palm and agrarian change in Sumatra, Indonesia. The Journal of Peasant Studies 37(4): 821-850. https://doi.org/10.1080 /03066150.2010.512460.

Muin A. 2013. Pengusahaan perkebunan kelapa sawit berwawasan konservasi [disertasi]. Bogor: Sekolah Pascasarjana, Institut Pertanian Bogor.

Nayantakaningtyas JS, Daryanto HK. 2012. Daya saing dan strategi pengembangan minyak sawit di Indonesia. Jurnal Manajemen dan Agribisnis 9 (3): 194-201.

Obidzinski K, Andriani R, Komarudin H, Andrianto A. 2012. Environmental and social impacts of oil palm plantations and their implications for biofuel production in Indonesia. Ecology and Society 17(1): 25. https://doi.org/10.5751/ES04775-170125.

Rist L, Feintrenie L, Levan P. 2010. The livelihood impacts of oil palm: smallholders in Indonesia. Biodiversity and Conservation 19(4):1009-1024. https://doi.org/10.1007/s10531-010-9815-z.
Sayer F, Ghazoul J, Nelson P, Boedhihartono AK. 2012. Oil palm expansion transforms tropical landscapes and livelihoods. Global Food Security 1: 114-119. http://dx.doi.org/10.1016/j. gfs.2012.10.003.

Seuring S, Muller M. 2008. From a literature review to a conceptual framework for sustainable supply chain management. Journal of Cleaner Production 16(15):1699-1710.https://doi. org/10.1016/j.jclepro.2008.04.020.

Sheil D, Casson A, Meijaard E, van Nordwijk M, Gaskell J, Sunderland-Groves J, Wertz K, \& Kanninen M. 2009. The impacts and opportunities of oil palm in Southeast Asia: What do we know and what do we need to know? Occasional paper no. 51. Bogor: CIFOR.

Simorangkir D. 2007. Fire use: is it really the cheaper land preparation method for largescale plantations? Mitigation and Adaptation Strategies for Global Change 12(1): 147-164. https://doi.org/10.1007/s11027-006-9049-2.

Sterman JD. 2000. Business Dynamics System Thinking and Modelling for a Complex World. New York: Mc Graw Hill.

Tacconi L. 2003. Fires in Indonesia: causes, costs, and policies. Occasional Paper No. 38. Bogor: Center for International Forestry Research, Bogor.

Tata HL, van Noordwijk M, Ruysschaert D, Mulia R, Rahayu S, Mulyoutami E, Darsoyo A, Oktaviani R, Dewi R. 2014. Will funding to Reduce Emissions from Deforestation and (forest) Degradation (REDD+) stop conversion of peat swamps to oil palm in orangutan habitat in Tripa in Aceh, Indonesia? Mitigation and Adaptation Strategies for Global Change 19:693-713.

Widodo KH, Abdullah A, Arbita KPD. 2010. Sistem supply chain crude-palm-oil Indonesia dengan mempertimbangkan aspek economical revenue, social welfare dan environment. Jurnal Teknik Industri 12(1): 47-54.

Widodo KH, Pramudya K, \& Abdullah A. 2011. Suply Chain Management Agroindustri yang Berkelanjutan. Bandung: Lubuk Agung.

World Bank. 2016. Kerugian dari kebakaran hutan, analisa dampak ekonomi dari krisis kebakaran tahun 2015. Laporan Pengetahuan Lanskap Berkelanjutan Indonesia: 1. 